Egyptian Journal of Aquatic Biology \& Fisheries

Zoology Department, Faculty of Science,

Ain Shams University, Cairo, Egypt.

ISSN $1110-6131$

Vol. 25(4): 719 - 739 (2021)

www.ejabf.journals.ekb.eg

\title{
Concurrent natural infection of Acanthocephalan species and Euclinostomum heterostomum synergistically increase Motile Aeromonas septicemia and Vibriosis in the Nile tilapia (Oreochomis niloticus)
}

\author{
Maather El-lamie ${ }^{1}$, Mona Ismail ${ }^{1}$, Salah M. Aly ${ }^{2}$, Eman Youssef ${ }^{3}$, Esraa Abdalla ${ }^{1}$ and \\ Hassnaa Elsheshtawy ${ }^{1} *$
}

1. Fish Diseases and Management Dept., Fac. of Vet. Medicine, Suez Canal University, Egypt.

2. Pathology Dept., Fac. of Vet. Medicine, Suez Canal University, Egypt.

3. Parasitology Dept., Fac. Of Vet. Medicine, Suez Canal University, Egypt

"Corresponding Author: Hassnaa_elshshtawy@vet.suez.edu.eg

\section{ARTICLE INFO}

Article History:

Received: June 22, 2021

Accepted: July 29, 2021

Online: Aug. 29, 2021

Keywords:

PCR technique,

Trematodes,

Acanthocephalans,

Aeromonas hydrophila,

Vibrio alginolyticus,

Vibrio parahaemolyticus

\section{ABSTRACT}

A seasonal study was performed on the wild Oreochomis niloticus collected seasonally from Suez channel, branched of the River Nile in Fayed region, Ismailia Governorate in Egypt. Specimens were addressed to investigate the role of natural infestation with parasites in secondary infection with Aeromonas and Vibrio species in a combination with unfavorable environmental condition. Acanthocephalans (Acanthocentis tilapiae and Neoechinorhynchus sp.) and trematode/ digenean Euclinostomum heterostomum were isolated from the intestine and kidneys of $O$. niloticus, respectively. Aeromonas hydrophila, Vibrio alginolyticus, and Vibrio parahaemolyticus were isolated from different organs of some examined tilapias and identified biochemically by VITEK®2 compac system and by PCR. The water quality parameters were significantly elevated over the permissible levels, whereas an annual average elevation was detected in nitrite $(0.06 \pm 0.08 \mathrm{mg} / \mathrm{L})$ and un-ionized ammonia $(0.31 \pm 0.29$ $\mathrm{mg} / \mathrm{L}$ ). The prevalence of co-infections of Motile Aeromonas Septicemia (MAS) with acanthocephalan was the highest in summer season (33.3\%). Additionally, the vibriosis with acanthocephalan infestation were the highest in summer $(66.7 \%)$ and the lowest in winter $(10.0 \%)$ in both cases. While coinfection of MAS with Euclinostomum heterostomum infestation together with the vibriosis were recorded the highest in summer with 50\% and $100 \%$, respectively, and the lowest was in winter (00.0\%) in both cases. Histopathological alterations were recorded in different organs as gills, liver, kidney and spleen in affected fish. It could be concluded that bad water quality and parasitism may depress immunity and stress fish facilitating Aeromonas and Vibrio infections.

\section{INTRODUCTION}

Egypt is the highest African country in tilapia production, mostly derived from either semi-extensive or semi-intensive pond systems using fresh and low saline brackish water (Soliman \& Yacout, 2016). The Nile tilapia, O. niloticus, is the most common and cheapest fish species available for Egyptians in the Nile River. In addition, it is one of the 
most important cultured tilapias worldwide (Lovshin, 1997). The tilapia adapt itself easily to changes in salinity levels and oxygen availability, and can feed at different trophic levels, and addingly under certain circumstances, it can tolerate overcrowding. Thus, it is an excellent species for aquaculture (Coward \& Little, 2001). Aquaculture problems can be summarized in 2 main factors, fish diseases and water pollution that are complementary to each other. Fish diseases are the result of an interaction between 3 major variables in the aquatic environments; fish (as a host; resistance, age and predisposed), pathogen (virulence and environmental requirements) and water environment (temperature, $\mathrm{pH}, \mathrm{O} 2$ level) (Austin \& Austin, 2007) . Fish -microorganism interactions are usually harmless if the immune system of fish is not compromised by a stressor. However, fish diseases frequently occur after fish are subjected to stressful conditions (Harper \& Wolf, 2009) . Fish diseases can arise from either infectious or non-infectious causes. Infectious causes include viruses, bacteria, fungi and parasites. Disorders in aquaculture conditions lead to changes in the parasite/host equilibrium, causing diseases and mortalities. Parasitism can cause mechanical damage (gill lamellae fusion and skin damage), physiological damage (cell proliferation and immunomodulation), and reproductive capacity damage (Iwanowicz, 2011). Remarkably, bacterial diseases are the most important causes of economic losses in the tilapia culture, including bacterial haemorrhagic septicaemia caused by several aeromonads including Aeromonas hydrophila (Austin et al., 2012). Additionally, Vibrio spp. were isolated from cultured tilapia after mass mortalities in farms around Qarun lake in Egypt (Younes $\boldsymbol{e} t$ al., 2016). The Aeromonas spp. are common pathogens causing Motile Aeromonas Septicemia (MAS) and result in high mortalities and economic losses (Zaman \& Khalequzzaman, 2013).Vibriosis severity depends on Vibrio species, which cause massive economic losses and clinical disease outbreaks (Abdel-Aziz et al., 2013). Parasitic infestations are considered as a stress factor; reducing fish resistance to secondary bacterial infections and act as a vehicle; transmitting bacterial pathogens by their damaging effects and opening a portal of entry with increased mortalities (Kotob $\boldsymbol{e t}$ al., 2017) or harboring bacteria and act as a source of infection for their hosts while feeding (Bowers et al., 2000). Mixed infections are common in $O$. niloticus intensive aquaculture (Xu et al., 2007). Moreover, they are common in free-living tilapias but are found at high rates in aquaculture. Due to the restriction measures in fish farms, some parasitic affections such as metacercarial infection are more common in free-living tilapias (El-Sayed $\boldsymbol{e t}$ al., 2019). Metacercarial infections appeared on fish in excessive mucus secretions, scale loss, respiratory distress, and colored spots or nodules on the affected organs resulting in atrophy of the affected organ (Aly et al., 2005). The deterioration of the physical and chemical properties of water such as temperature, alkalinity, un-ionized ammonia (NH3), dissolved oxygen (DO), nitrite ( $\mathrm{NO} 2$ ), $\mathrm{pH}$ value and total hardness has a strong influence on the fish health status as it reduces their immune response and increases their susceptibility to the invading bacterial and parasitic 
pathogens (Hossain et al., 2007). Therefore, in the present study, the occurrence of natural co-infection was examined with some parasites and MAS or vibriosis among $O$. niloticus. Moreover, this work aimed to assess the clinical picture of the affected fishes and its relationship with the deteriorated water quality parameters and the prevalence of mixed infections while highlighting the histopathological alterations due to these coinfections.

\section{MATERIALS AND METHODS}

\section{Fish collection and sampling}

A total of 121 wild $O$. niloticus (moribund and/or freshly dead), with weights $\geq 70$ $\geq 99 \mathrm{~g}$, were collected seasonally from Suez channel; branched of Nile river in Fayed region, Ismailia Governorate, Egypt from September 2018 to August 2019. The sampling patterns during the different seasons were as follows: 26 in winter, 35 in spring, 28 in summer, and 32 in autumn. The collected samples were transferred immediately to the laboratory of Fish Diseases and Management, Faculty of Veterinary Medicine, Suez Canal University for further investigation

\section{Ethical considerations}

This work contains a surveillance study that aimed to determine the possible cause of the fish mortalities and does not need ethical approval. Fish before examination were euthanized by pithing according to Barker et al. (2002)

\section{Clinical and postmortem examinations}

Fish samples were clinically examined for any abnormal clinical signs and gross lesions. Clinical and postmortem examinations were carried out according to Noga (2010).

\section{Water quality parameters}

Throughout the survey period (from September 2018 to August 2019), 10 water samples / season were collected from different sites in the lake and were put in sterile 500 $\mathrm{ml}$ glass bottles according to the standard methods of APHA (1981). Water parameters; namely, temperature, dissolved oxygen and the $\mathrm{pH}$ were measured on spot using alcoholic thermometer, oxygen metre and $\mathrm{pH}$ metre, respectively. Kits were utilized for measuring the levels of un-ionized ammonia and nitrite found in the water (USA, Virginia Company, lot. No. 201134).

\section{Parasitological assay}

Internal organs were dissected out and examined under a stereozoom microscope (Zeiss- Germany). Live parasites were examined; their morphological details were recorded for further taxonomic determination. Small pieces from internal organs were cut, compressed between two slides, and examined microscopically for the presence of encysted metacercariae (EMC). Their morphological details were addressed, then samples were fixed and mounted. Acanthocephalans were fixed, stained and mounted following the method of Noga (2010). 


\section{Bacteriological assay}

It was performed according to the method of Buller (2014). A loopful of hepatopancreas, kidney, gills, and spleen were inoculated in nutrient broth (NB) (LAB M) and incubated at $25^{\circ} \mathrm{C}$ for $24 \mathrm{~h}$. Positive turbid cultured broths were sub-cultured on nutrient agar (NA, LAB M). The recovered colonies were inoculated onto specific media; Thiosulfate citrate bile salt sucrose agar (TCBS) and Aeromonas base agar (LAB M), and left incubated at $24^{\circ} \mathrm{C}$ for $24 \mathrm{~h}$. The suspected colonies of Vibrio and Aeromonas species were identified biochemically using standard methods, and were confirmed by VITEK®2 compac systems (Biomerieux). All isolates were stored at $-80^{\circ} \mathrm{C}$ in Brain Heart Infusion Broth (BHIB) with $3 \% \mathrm{NaCl}$ and $20 \%$ glycerol according to Gauthier et al. (1995).

7. Molecular characterization of bacterial species

\subsection{Bacterial DNA extraction}

Genomic DNA was extracted by the boiling centrifugation method (Soumet et al., 1994). Following the technique of Mendes-Marques et al. (2013), the conventional and Duplex PCR technique was used to detect Aeromonas hydrophila and Vibrio alginolyticus and Vibrio parahaemolyticus, respectively.

7.2. Oligonucleotide designs for collagenase, toxR, and 16SrRNA genes amplification

As shown in Table (1), the nucleotide sequence of collagenase gene, partial toxR gene, and 16SrRNA gene primers were obtained according to Kim et al. (1999), Gordon et al. (2007) and Abu-Elala et al. (2016), respectively. They were used for the identification of Vibrio alginolyticus (V. alginolyticus), Vibrio parahaemolyticus (V. parahaemolyticus), and Aeromonas hydrophila (A. hydrophila) strains.

Table 1: Oligonucleotide primer sequences for Vibrio spp. and genus Aeromonas and A. hydrophila

\begin{tabular}{|c|c|c|c|}
\hline Target & $\begin{array}{l}\text { Sequence } \\
\left(5^{\prime}-3^{\prime}\right)\end{array}$ & $\begin{array}{c}\text { Amplified } \\
\text { product }\end{array}$ & Reference \\
\hline V. alginolyticus & CGAGTACAGTCACTTGAAAGCC & $737 \mathrm{hn}$ & Abu-Elala et al., \\
\hline Collagenase & CACAACAGAACTCGCGTTACC & $13 /$ op & 2016 \\
\hline$V \cdot$ parahaemolyticus & GTCTTCTGACGCAATCGTTG & $368 \mathrm{hn}$ & Kim et al 1000 \\
\hline tox $R$ & ATACGAGTGGTTGCTGTCATG & $308 \mathrm{pp}$ & KIm et al., 1999 \\
\hline Aeromonas genus $16 \mathrm{~S}$ & CTACTTTTGCCGGCGAGCGG & $953 \mathrm{bp}$ & \\
\hline rRNA & TGATTCCCGAAGGCACTCCC & & Gordon et al., \\
\hline $\begin{array}{l}\text { Aeromonas hydrophila } \\
\text { 16S rRNA }\end{array}$ & $\begin{array}{l}\text { GAAAGGTTGATGCCTAATACGTA } \\
\text { CGTGCTGGCAACAAAGGACAG }\end{array}$ & $625 \mathrm{bp}$ & 2007 \\
\hline
\end{tabular}




\subsection{PCR amplification and agarose gel electrophoresis}

The PCR reaction was run in a thermal cycler (Techne, England). A typical mixture of $5 \mu \mathrm{l}$ of the extracted DNA, $12.5 \mu \mathrm{l}$ PCR master mix (2X DreamTaq Green mastermix kit), $1 \mu \mathrm{l}$ of forward and reverse primers in a volume of $25 \mu \mathrm{l}$. was prepared. The DNA denaturation was carried out at $94^{\circ} \mathrm{C}$ for $5 \mathrm{~min}$, and then a total of $35 \mathrm{PCR}$ cycles were run under the following conditions: DNA denaturation at $94^{\circ} \mathrm{C}$ for $30 \mathrm{~s}$, primer annealing at $50^{\circ} \mathrm{C}$ for $40 \mathrm{~s}$ and DNA polymerization at $72^{\circ} \mathrm{C}$ for $45 \mathrm{~s}$. After the final cycle, reactions were terminated at $72^{\circ} \mathrm{C}$ for $10 \mathrm{~min}$ as a final extension step for the two genes. Agarose gel electrophoresis was performed by the addition of $6 \mu$ of PCR product for each sample in $1.5 \%$ agarose containing ethidium bromide stain $(0.5 \mu \mathrm{g} / \mathrm{ml})$. A $100 \mathrm{bp}$ DNA ladder (NZYDNA Ladder V) was used as a molecular weight marker according to Sambrook and Fritscgh (1989). PCR products were compared using the SynGene Gel Documentation System. V. alginolyticus give bands at $\sim 737 \mathrm{bp}$, V. parahaemlyticus at $\sim 368 \mathrm{bp}$, Aeromonas species at $\sim 953 \mathrm{bp}$, and A. hydrophila at $\sim 625 \mathrm{bp}$.

\section{Histopathological examination}

Small pieces of infected organs (liver, kidney, spleen and gills) with visible lesions were taken and preserved in $10 \%$ neutral buffered formalin, dehydrated by ascending grades of ethyl alcohol (70, 80, 90 and 100\%), cleared in 50\% alcohol-xylol mixture, embedded in paraffin wax, and then sectioned at $5 \mu \mathrm{m}$ thickness, mounted on a glass slide and stained with H\&E according to Korun and Timur (2005).

\section{RESULTS}

\section{Clinical signs and postmortem lesions}

Infected fish showed emaciated body and respiratory manifestations. Hemorrhages all over the body surface or black discoloration of the skin were also observed. Loss of scales were recorded in some cases. Other cases showed exophthalmia (Fig. 1.A.), ascites, and hyperemic protruded vent with an emaciated body. Gills had marbling appearance with excessive mucus secretions. Internally, there was accumulated serous, cloudy, or bloody fluid in the abdominal cavity. Hepatopancreas showed congestion with mottled appearance or yellowish discoloration. In some cases, the spleen revealed congestion and enlargement. While others, showing congested stomach and intestine with thick intestinal wall and excessive mucus secretions in their lumens, were observed (Fig. 1.B.). Kidneys were congested and enlarged; sometimes had attached yellow-white cyst(s) $(3 \mathrm{~mm} \times 5 \mathrm{~mm})$ (Fig. 1.C.). Some cases showed gas bubbles in the intestinal lumen, and others appeared with attached parasitic helminthes to the inner wall of the intestine. 


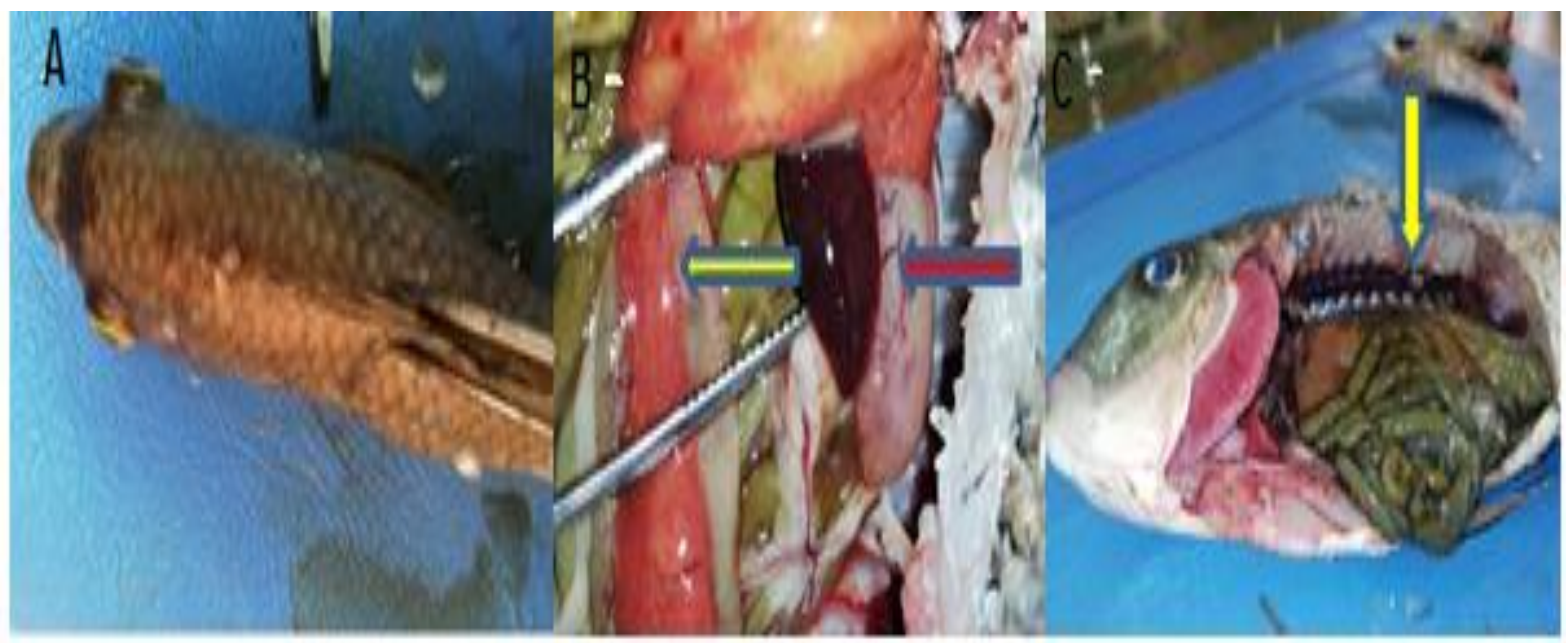

Fig. 1: Photographs of mixed infected O. niloticus showing (A) Bilateral exophthalmia, (B) Congested and enlarged spleen, congested stomach (red arrow) and intestines (yellow arrow) with thick intestinal wall and excessive mucus secretions in their lumens and $(\mathbf{C})$ Congested kidneys with $(3 \mathrm{~mm} \times 5 \mathrm{~mm})$ attached yellow-white cyst (arrow).

\section{Physiochemical parameters of water samples}

The physical and chemical properties of canal water were illustrated in (Table 2) during different seasons of this study, whereas the annual average of DO was $(6.2 \pm 1.58$ $\mathrm{mg} / \mathrm{L})$, the $\mathrm{pH}$ value was $(7.9 \pm 0.20)$, and the water temperature was $\left(25.2 \pm 5.1^{\circ} \mathrm{C}\right)$. In comparison with the standard values of WHO (1993), an elevation was spotted in the nitrite (NO2) (0.06 $\pm 0.08 \mathrm{mg} / \mathrm{L})$ and the un-ionized ammonia (NH3) $(0.31 \pm 0.29 \mathrm{mg} / \mathrm{L})$.

Table 2: The mean values of seasonal variations of physical and chemical properties of examined water during the study and their relation to the standard permissible limits (mean \pm standard deviation

\begin{tabular}{llllll}
\hline Season & $\begin{array}{l}\text { Dissolved } \\
\text { oxygen }(\mathbf{D O}) \\
(\mathbf{m g} / \mathbf{L})\end{array}$ & $\begin{array}{l}\text { Temprature } \\
\left({ }^{\circ} \mathbf{C}\right)\end{array}$ & pH value & $\begin{array}{l}\text { NH3 } \\
(\mathbf{m g} / \mathbf{L})\end{array}$ & $\begin{array}{l}\text { NO2 } \\
(\mathbf{m g} / \mathbf{L})\end{array}$ \\
\hline Winter & $6.5 \pm 0.7$ & $17.90 \pm 6.4$ & $8.04 \pm 2.9$ & $0.2 \pm 0.3$ & $0.01 \pm 0.1$ \\
Spring & $8.60 \pm 0.4$ & $28.03 \pm 5.9$ & $7.95 \pm 0.5$ & $0.071 \pm 0.04$ & $0.02 \pm 0.2$ \\
Summer & $4.28 \pm 0.4$ & $31.5 \pm 6.7$ & $7.58 \pm 0.5$ & $0.8 \pm 0.6$ & $0.2 \pm 0.3$ \\
Autumn & $5.5 \pm 0.6$ & $23.40 \pm 6.2$ & $8.11 \pm .0 .7$ & $0.15 \pm 0.02$ & $0.015 \pm 0.2$ \\
Annual average & $6.22 \pm 1.58$ & $25.20 \pm 5.1$ & $7.92 \pm 0.20$ & $0.31 \pm 0.29$ & $0.06 \pm 0.08$ \\
Permissible limits (WHO, & $5-6$ & & $8-8.5$ & 0.01 & 0.01 \\
$\mathbf{1 9 9 3 )}$ & & & & & \\
\hline
\end{tabular}




\section{Parasitological examination}

Microscopic examination revealed two acanthocephalan species from the intestine with a club-shaped and elongated body with a retractable proboscis. The first acanthocephalan species, after staining with Semichon's acetocarmine, thee rows of six hooks were observed curving posteriorly in both sexes. Tegument had alternative folds and pores. Lemnisci were two mononucleated, unequal blind and compact. The reproductive system in the posterior half of the trunk extended to the posterior end of the bursa. Morphologically, it is related to Order Gyracanthocephala Family: Quadrigyridae, Genus: Acanthogyrus, Species: Acanthosentis tilapiae according to Baylis (1947) as presented in Fig. (2.D.). The second acanthocephalan is characterized by females being twice as large as males. All other shared structures were of similar size and shape in both sexes. The trunk was arched, long, and slender. The epidermal surface was porous. Proboscis was as long as wide. Proboscis hooks were equal in each circle, and circles of hooks were evenly spaced. Proboscis receptacle had a large pyramid-shaped cephalic ganglion at its base. Lemnisci were of comparable sizes in both sexes, much longer than the receptacle. Morphologically, it is related to Class: Eoacanthocephala Order: Neoechinorhynchida Family: Neochinorhynchidae, Genus: Neochinorhynchinus Species Neochinorhynchinus species according to Stiles and Hassall (1905), and the data are showed in Fig. (2.E.). Gross examination revealed a well-defined yellowish-white visible cyst $(3 \mathrm{~mm} \times 5 \mathrm{~mm})$ attached to and/or embedded in kidneys. After excystation, staining, and microscopic examination, a characteristic black and tree-like branched intestine was monitored with the presence of oral and ventral suckers. Morphologically, this EMC is related to Family: Clinostomatidae, Genus: Euclinostomum, Species: Euclinostomum heterostomum (E. heterostomum) according to Dönges (1974) (Fig. 2.F.).

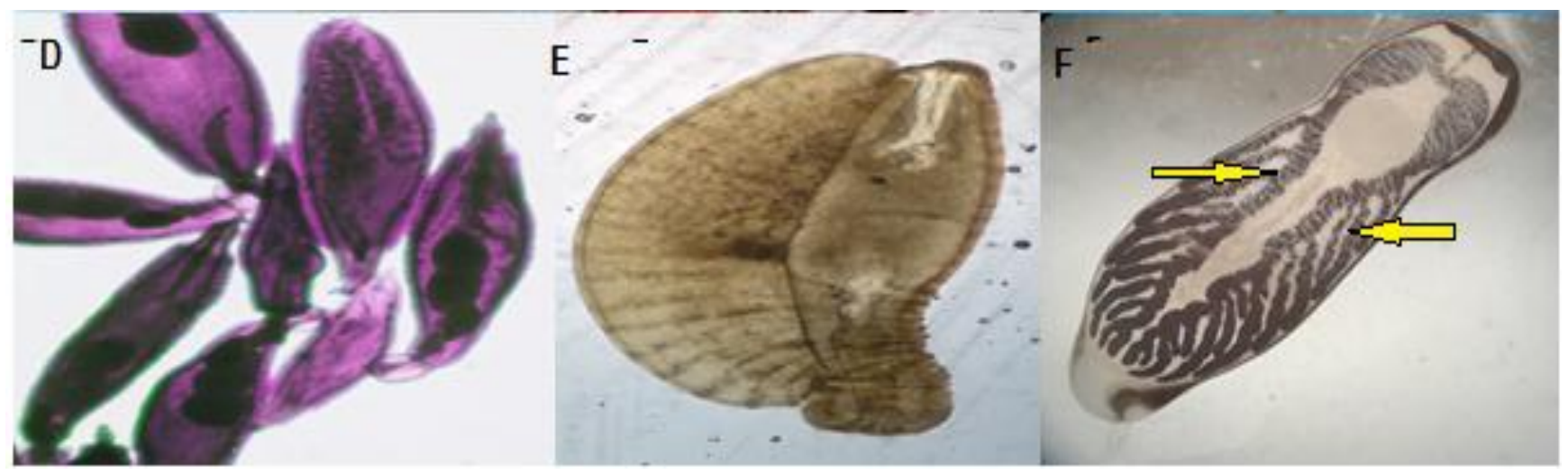

Fig. 2: Photomicrographs showing (D) Heavy infestation with Semichon's acetocarmine stained Acanthocentis tilapiae (male and female), (E) Unstained Neoechinorhynchus sp., and (F) Unstained excysted E. heterostomum with black and branched intestine (arrows). 


\section{Bacteriological examination}

The isolated colonies of $V$. alginolyticus and $V$. parahaemolyticus on nutrient agar were medium-sized (2-3 $\mathrm{mm}$ in diameter) and creamy in color, while A. hydrophila appeared as grey-white translucent colonies. On Thiosulphate citrate bile salt agar (TCBS), colonies of $V$. alginolyticus were swarming and yellow-colored, $V$. parahaemolyticus were swarming, green-colored with yellow pigmentation, and $A$. hydrophila appeared as homogenous yellow colonies and cannot be picked as a separate colony. On Aeromonas base agar medium, Vibrio species did not grow while $A$. hydrophila colonies appeared as dark green, opaque with darker center with a diameter of 0.5-1.5 mm. Microscopic examination revealed that Vibrio species were gram-negative, comma or rod-shaped, motile bacteria, and scattered in arrangement. They were oxidase, and catalase tests positive. The Aeromonas hydrophila was gram-negative, rod-shaped bacilli with rounded ends, motile, catalase and oxidase tests positive. Results of the phenotypic characters and biochemical test of $V$. alginolyticus, $V$. parahaemolyticus and A. hydrophila by traditional methods are listed in Table (3). VHTEK®2 compac system confirmed that the isolates were $V$. alginolyticus, $V$. parahaemolyticus and A. hydrophila with probability of $95 \%, 96 \%$, and $86 \%$, respectively

Table 3: The morphological and biochemical characteristics of the isolated bacterial species

\begin{tabular}{|c|c|c|c|}
\hline Test & V. alginolyticus & V.parahaemolyticus & A. hydrophila \\
\hline Gram staining & $\begin{array}{l}\text { (-ve) short, coma } \\
\text { shaped bacilli }\end{array}$ & $\begin{array}{l}\text { (-ve) short, coma } \\
\text { shaped bacilli }\end{array}$ & $\begin{array}{l}\text { (-ve) rod-shaped with } \\
\text { rounded ends }\end{array}$ \\
\hline TCBS & $\begin{array}{l}\text { Yellow-colored } \\
\text { colonies }\end{array}$ & $\begin{array}{l}\text { Scattered green with } \\
\text { yellow pigmentation } \\
\text { colonies }\end{array}$ & $\begin{array}{c}\text { Homogeneous yellow } \\
\text { colonies }\end{array}$ \\
\hline Aeromonas base agar media & - & $\cos$ & $\begin{array}{l}\text { dark green, opaque } \\
\text { with a darker center }\end{array}$ \\
\hline Hemolysis & + & + & B hemolysis \\
\hline Oxidase & + & + & + \\
\hline Catalase & + & + & + \\
\hline \multicolumn{4}{|l|}{ Growth on medium with } \\
\hline $0 \%$ & - & - & + \\
\hline $3 \%$ & + & + & ++ \\
\hline $6 \%$ & + & + & - \\
\hline $8 \%$ & + & + & - \\
\hline $10 \%$ & + & + & - \\
\hline \multicolumn{4}{|l|}{ Growth temperature, ${ }^{\circ} \mathrm{C}$} \\
\hline $4^{\circ} \mathrm{C}$ & - & - & + \\
\hline
\end{tabular}




\begin{tabular}{|c|c|c|c|}
\hline $25 \& 37^{\circ} \mathrm{C}$ & + & + & + \\
\hline $42{ }^{\circ} \mathrm{C}$ & + & + & - \\
\hline $\begin{array}{l}\text { Arginine dihydrolase } \\
\text { production }\end{array}$ & - & - & + \\
\hline $\begin{array}{l}\text { Lysine decarboxylase } \\
\text { production }\end{array}$ & + & + & + \\
\hline $\begin{array}{l}\text { Ornithine decarboxylase } \\
\text { production }\end{array}$ & \pm & \pm & - \\
\hline Citrate utilization & + & + & + \\
\hline $\mathrm{H}_{2} \mathrm{~S}$ production $\left(\mathrm{H}_{2} \mathrm{~S}\right)$ & - & - & + \\
\hline Urease production & \pm & \pm & - \\
\hline $\begin{array}{l}\text { Tryptophane deaminase } \\
\text { production (TDA) }\end{array}$ & - & - & - \\
\hline Indol production & \pm & \pm & + \\
\hline Acetoin production & - & \pm & + \\
\hline Gelatinase production GEL) & + & + & + \\
\hline Acid from glucose & + & + & + \\
\hline Acid from mannitol (MAN) & + & + & + \\
\hline Acid from inositol (INO) & - & - & - \\
\hline Acid from Sorbitol (SOR) & - & - & - \\
\hline Acid from sucrose & - & + & + \\
\hline Acid from arabinose (ARA) & \pm & \pm & Variable \\
\hline
\end{tabular}

\section{Molecular identification of bacterial strains}

It was yielded amplification products of expected molecular size at $737 \mathrm{bp}$ and $368 \mathrm{bp}$ specific for $V$. alginolyticus and $V$. parahaemolyticus strains, respectively, as shown in Fig. (3). Detection of Aeromonas species using 16SrRNA amplicon represented genus Aeromonas at $953 \mathrm{bp}$ and $A$. hydrophila at 652 bp as shown in Fig. (4).

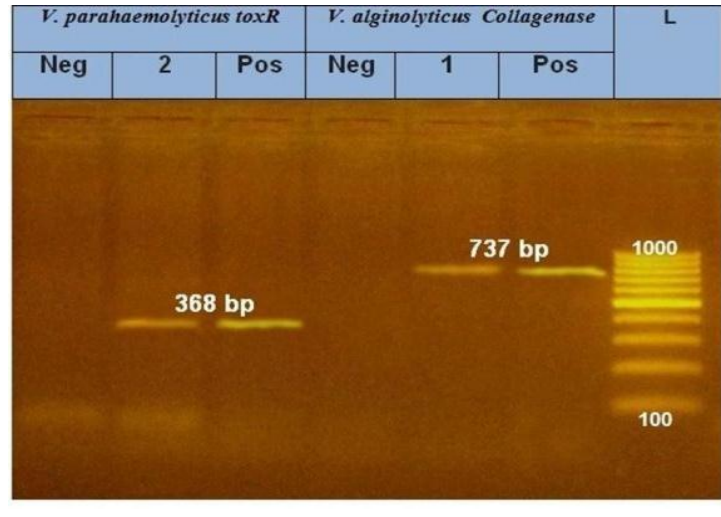

Fig. 3: A photograph showing 737bp and 368bp amplicons representing collagenase and toxR genes in $V$. alginolyticus and V.parahemolyticus, respectively. Neg.: Negative, Pos Positive, L: 100 bp DNA ladder, 1 sample 1, 2: sample 2

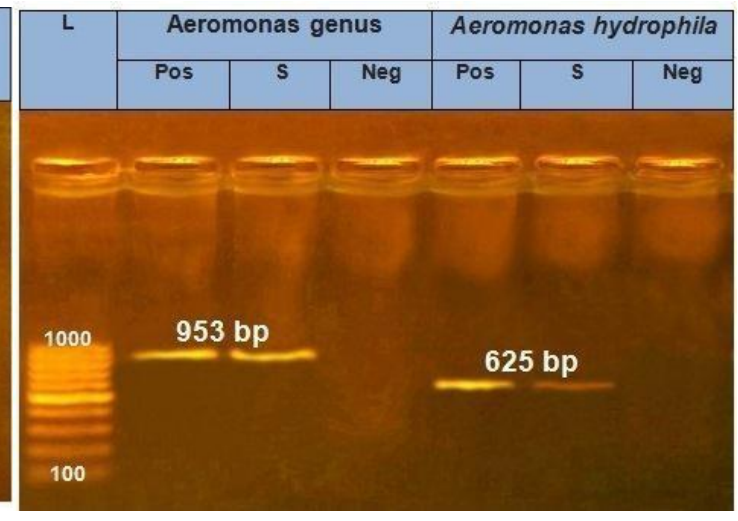

Fig. 4: 16S rRNA amplicon representing genus Aeromonas at 53bp and Aeromonas hydrophila at 652bp. Neg.: Negative, Pos: Positive, L: 100 bp DNA ladder, s: sample 


\section{Prevalence of infections}

Prevalence of acanthocephalan infestation was higher than that of the $E$. heterostomum. The highest prevalence for acanthocephalan were recorded in summer $(57.1 \%)$ and the lowest were in winter (31.3\%). While for E. heterostomum infestations, the highest was in autumn (15.4\%) and the lowest in winter (3.1\%) (Fig. 5). The total prevalence of Motile Aeromonas Septicemia (MAS) and vibriosis were $19.8 \%$ and $20.7 \%$, respectively with the highest prevalence in summer $(28.6 \%),(35.7 \%)$ and the lowest in spring (11.4\%) and winter (11.5\%), respectively (Table 4). Prevalence of MAS in fishes infested with acanthocephalan and E. heterostomum EMC were $(53.3 \%)$ and $(30.8 \%)$, respectively. The MAS recorded the highest prevalence in summer $(33.3 \%)$ and (50\%) and the lowest in winter $(10 \%)$ and $(0 \%)$ in infested acanthocephalan and E. heterostomum fish, respectively. Prevalence of vibriosis in infested fishes with acanthocephalan and E. heterostomum were (56.6\%) and (46.2\%), respectively. It recorded the highest prevalence of $66.7 \%$ and $100 \%$ in summer, and the lowest prevalence were in winter $(10 \%)$ and $(0 \%)$ in acanthocephalan and E. heterostomum infested fish, respectively (Fig. 6).

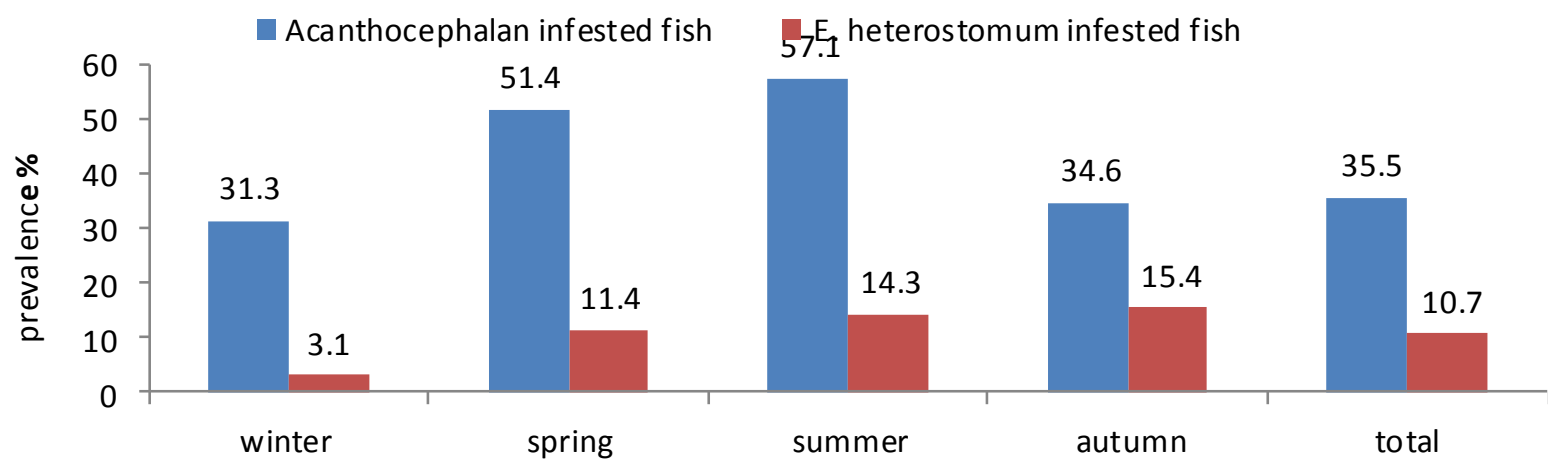

Fig. 5: Total and seasonal prevalence of $O$. niloticus infested with different parasites

Table 4: Total and seasonal prevalence of MAS, vibriosis and mixed bacterial infection in wild $O$. niloticus

\begin{tabular}{lccccc}
\hline & $\begin{array}{c}\text { Winter } \\
\mathbf{n = 2 6}\end{array}$ & $\begin{array}{c}\text { Spring } \\
\mathbf{n = 3 5}\end{array}$ & $\begin{array}{c}\text { Summer } \\
\mathbf{n = 2 8}\end{array}$ & $\begin{array}{c}\text { Autumn } \\
\mathbf{n = 3 2}\end{array}$ & $\begin{array}{c}\text { Total } \\
\mathbf{n = 1 2 1}\end{array}$ \\
\hline $\begin{array}{l}\text { Type of infection in } \boldsymbol{O} \text {. niloticus } \\
\text { MAS }\end{array}$ & $5(19.2 \%)$ & $4(11.4 \%)$ & $8(28.6 \%)$ & $7(21.9 \%)$ & $24(19.8 \%)$ \\
Vibriosis & $3(11.5 \%)$ & $8(22.9 \%)$ & $\begin{array}{c}10 \\
(35.7 \%)\end{array}$ & $4(12.5 \%)$ & $25(20.7 \%)$ \\
Mixed (MAS + vibriosis) & $8(30.8 \%)$ & 10 & $9(32.1 \%)$ & $7(21.9 \%)$ & $37(30.6 \%)$ \\
Total number of infected fish & $8(30.8 \%)$ & $(34.3 \%)$ & $(64.3 \%)$ & $(34.4 \%)$ & $49(40.5 \%)$ \\
\hline
\end{tabular}




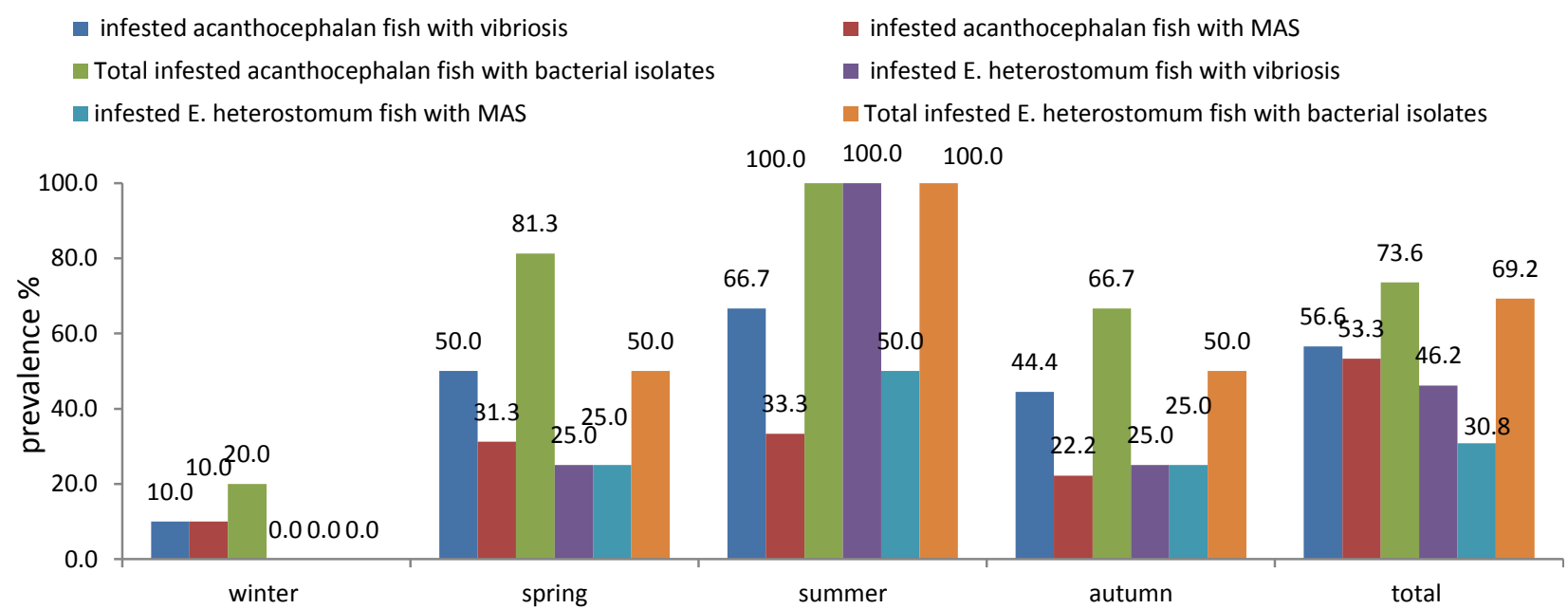

Fig. 6: Total and seasonal prevalences of mixed infected O.niloticus ( MAS and vibriosis with each parasite)

\section{Histopathological examination}

The Nile tilapia infected with MAS and vibriosis in the presence of parasitic infestations revealed degeneration and necrosis of secondary lamellae with congestion. The kidney showed vacuolar degeneration and necrosis of renal tubules and focal leukocytic infiltration. The spleen showed severe destruction of hematopoietic tissue and mild hyperplasia of melanomachrophage cells. Hepatopancreas revealed advanced vacuolar degeneration in hepatocytes. Some hepatic cells were necrotic and they lacked nuclei. The pancreatic acini showed degeneration and necrosis of the pancreatic cells and congested pancreatic vessels (Fig. 7). 


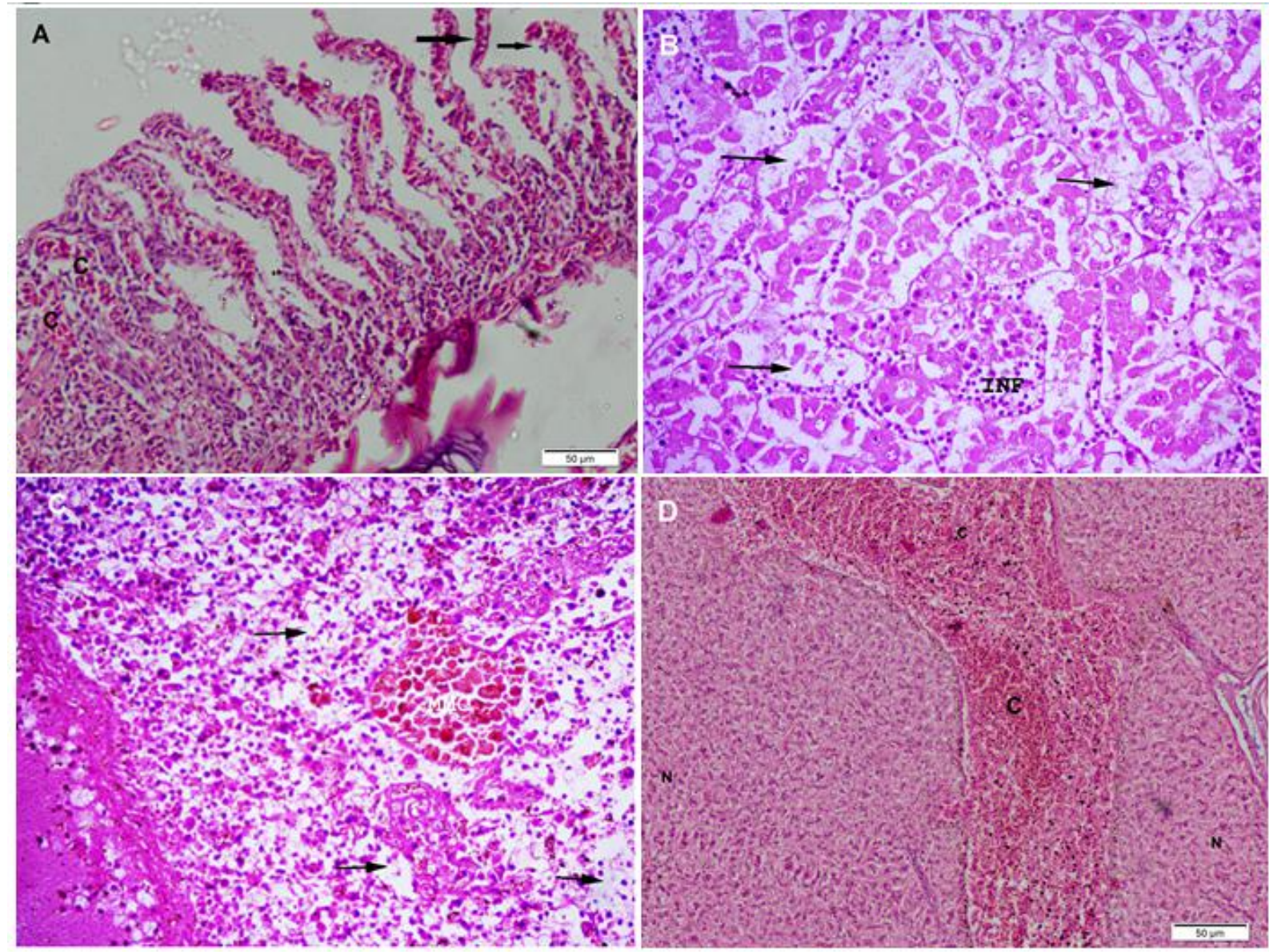

Fig. 7: Photomicrographs of histopathological examination of naturally mixed infected O. niloticus: (A) Gills showing degeneration and necrosis of secondary lamellae (arrow) with congestion (C) (B) Anterior kidney showing vacuolar degeneration and necrosis of renal tubules (arrows) and focal leukocytic infiltration (INF). (C) Spleen showing severe destruction of hematopoietic tissue (arrows) and mild hyperplasia of melanomachrophage cells (MMC). (D) Hepatopancreas showing advanced vacuolar degeneration (N) in hepatocytes. Some hepatic cells were necrotic and lacked nuclei. The pancreatic acini showed degeneration and necrosis of the pancreatic cells and congested pancreatic vessels (C) (arrows) .

\section{DISCUSSION}

Fish diseases are stress related with a multifactorial nature (Austin \& Austin, 1993). Concurrent infections are common in aquatic ecosystems due to the presence of multifactors affecting fish health. Parasitic infestations act as a stress factor increasing secondary bacterial infections by different methods (Kotob et al., 2017) or harboring bacteria and act as a source of infection while feeding (Bowers $\boldsymbol{e t}$ al., 2000). In this study, the clinical signs and post-mortem lesions of the diseased tilapia showed emaciated body and typical signs of septicaemia that included exophthalmia, ascites, hemorrhages 
all over the body surface or as black discoloration of the skin and hyperemic protruded vent. The current results are in concordance with the findings reported by Plumb (1999), Diggles et al. (2000) and Eissa (2002). Additionally, congested gills, liver spleen and kidney were detected with accumulation of bloody tinged in the abdominal cavity and thickening of intestinal wall with excessive mucus secretions in their lumens. These findings concur with that reported by Lunder et al. (2000), El-Ashram (2002), Korun and Timur (2008), Sarkar and Rashid (2012) and Dahdouh et al. (2016). The gross lesions and P.M findings could be attributed to various factors; among which is the pathogenic characters of the bacteria including invasion, multiplication and colonization. The action of the bacterial exotoxins (toxic extracellular metabolites) of A. hydrophila and $V$. alginolyticus and V.paraheamolyticus also played an important role in the formation of the haemolysin, aerolysin and cytotoxic toxins due to their haemolytic, cytolytic and enterotoxic activities (Stintzi \& Raymond, 2000; Eissa et al., 2013) Another facor that is worthy mentioning is the synergistic, parasitic and bacterial interactions which increase the disease occurrence (Kotob et al., 2017). Furthermore, the acanthocephalans' role in competing for nutrients and decreasing protein ratio in musculature (Wanstall \& Terry, 1984) together with their presence in the intestine resulted in impaired nutrient absorption (Nickol, 2006).

In the present study, water quality parameters revealed elevations of non ionized ammonia and nitrite that surpassed the permissible limits in a way that may multiply the disease. This could happen because the deterioration of physicochemical water quality parameters may act as potential environmental stressors, and thus predispose fish for infectious agents (Evans et al., 2006). The results of poor water quality were associated with the infection of the Nile tilapia with bacterial and parasitic diseases. This may be attributed to the deteriorated water quality parameters that have significantly increased the susceptibility to various pathogenic bacteria and parasites and led to disease outbreaks (Glibert et al., 2002).

Based on the convention of morphological, biochemical identification and VITEK®2 Compac system characterization of the bacterial isolates, the identification of the $A$. hydrophila strains was achieved. These findings are in agreement with those of Abbott $\boldsymbol{e t}$ al. (2003), Garrity (2005) and Cai et al. (2012). On the other hand, the bacterial isolates of V. alginolyticus and $V$. parahaemolyticus coincide with those of Elamparithi and Ramanathan (2011), Lee et al. (2015) and Eissa et al. (2019) .

In this study, the sequence of the universal 16SrRNA gene was used to identify $A$. hydrophila with a typical homology at $625 \mathrm{pb}$ (Gordon et al., 2007). Additionally, the PCR analysis for the detection of virulence genes revealed that, all bacterial isolates of $V$. alginolyticus and $V$. parahemolyticus strains contained collagenase and toxR genes at their specific segment sizes 737bp (Abu-Elala et al., 2016) and 368 bp (Kim et al., 1999) , respectively. This findings could explain the detected haemorrhagic, ulcerative and septicaemic signs of the infected fish in the current study. 
Notably, the parasitological examination revealed the existence of two acanthocephalan parasites isolated from the intestine: Acanthosentis tilapiae (Bayoumy et al., 2006) and Neochinorhincus sp. (de la Cruz et al., 2013). The number and arrangement of hooks were the basis for identification to genus level. Additionally, the existence of the E. heterostomum excysted metacercaria resembles that detected in the study of Taher (2009). Total prevalence of acanthocephalan and vibriosis coinfection (56.6\%) were more than acanthocephalan and MAS coinfection (53.3\%) as many Vibrio spp. prefer entrance at foregut (Chen $\boldsymbol{e t}$ al., 2008); the favorable site for acanthocephalan parasites (Ebtsam et al., 2017). Acanthocephalans facilitate entrance of opportunistic bacteria through the damaged intestinal villi (El-Mansy, 2011), and they attract more local immunity (Dezfuli et $\boldsymbol{a l} .$, 2015) that leads to a decrease in the external surface defense mechanism of the fish. Besides, the leakage of blood protein, due to their feeding behavior (Szalai \& Dick, 1987), may affect the serum protein level used for the production of immunoglobulins which opsonizes pathogens (Janeway et al., 2004).Thus, the pathogenicity and the incidence of vibriosis was higher than Motile Aeromonas Septicemia. The prevalence of E. heterostomum coinfections with Motile Aeromonas Septicemia was $30.8 \%$, while together with vibriosis, the percentage was $46.2 \%$. These results may be attributed to the fact that, the mechanical injures resulting from cercarial penetration are related to the transmission of opportunistic bacteria through the dermal route (Abdelaziz et al., 2017). E. heterostomum EMC mostly affects kidneys and hepatopancreas (Caffara $\boldsymbol{e t}$ al., 2016), which are hematopoietic organs responsible for immunity and detoxification. Hence, it gives a chance for more opportunistic bacterial infections (Yildiz et al., 2005). Regarding seasonal prevalence, MAS and vibriosis in $O$. niloticus infested with acanthocephalan parasites, results revealed $53.3 \%$ and $56.6 \%$ in summer. This may be due to the high acanthocephalan infestation rate in this season (57.1\%). Vibriosis increased by increasing intestinal acanthocephalans opening more portals for entry (Abram et al., 2017). Besides, the increase of temperature during summer (Austin and Austin, 2007) causes an imbalance of physicochemical water quality parameters that may act as potential environmental stressors. Hence, the aforementioned condition would predispose fish to infectious agents; either bacterial or parasitic (Plumb et al., 1976). Winter was the lowest season of coinfection (10\%) between MAS and vibriosis in fish infested with acanthocephalan parasites, this may be attributed to the good immunity of fish at $15^{\circ} \mathrm{C}$ (Abbas et al., 2008), but vibriosis is able to infect fish though its favorable site (intestinal tract) (Chen et al., 2008). In this study, Motile Aeromonas Septicemia and vibriosis in E. heterostomum infested O. niloticus were the highest prevalence 50\% and $100 \%$ were recorded in summer season respectively, and $0 \%$ were the lowest prevalence recorded in winter season; this may be due to the availability of intermediate hosts of these parasites at these seasons and increase the feeding activity in warm temperature (Shehata et al., 2018). 
Concerning the histopathological findings, the liver, kidney and spleen are known for their affinity to trap the circulating pathogens, and so, they act as the target organs for many diseases (Agius and Roberts, 2003). In the current study, several histopathological changes were revealed degeneration and necrosis of secondary lamellae of infected Nile Tilapia gills with congestion in some areas, these agreed with the findings of . Kidney showing vacuolar degeneration and necrosis of renal tubules and focal leukocytic infiltration. Spleen showed severe destruction of hematopoietic tissue and mild hyperplasia of melanomachrophage cells.. Our results were much like the findings found in other fish species in previous investigations (Mahdy et al., 2017) and (Eissa et al., 2019) in Sparus auratus and Mugil cephalus infected with vibriosis and Euclinostomum spp. The hepatopancreas revealed advanced vacuolar degeneration in hepatocytes. Some hepatic cells were necrotic and lack nuclei. The pancreatic acini showed degeneration and necrosis of the pancreatic cells and congested pancreatic vessels. These findings were in concordance with that reported by Ismail et al. (2011), who recorded the same results but in Mugil capito infected with vibriosis. These lesions could be attributed to the lack of oxygen resulting from gills degeneration (Yardımcı and Aydın, 2011) and bacterial toxins. Moreover, the activation and hyperplasia of melanomacrophage cells were evident in the spleen of infected fish. These pigmented cells may appear in the form of a cluster where it indicates the positive presence of neutral carbohydrate and melanin (Agius and Roberts, 2003) .

\section{ACKNOWLEDGMENT}

The authors are grateful to the team of Fish Diseases and Management Department, Faculty of Veterinary Medicine, Suez Canal University, Ismailia, Egypt, for their care of fish samples and laboratory works. We would also like to thank Prof. Dr. Ismail Abd ElMoem Eissa for his assistance and useful guidance.

\section{REFERENCES}

Abbas, H. H.; Ali, F. K. and Kenawy, A. M. (2008). Assessment study about using underground water for tilapia culture for the first time in El-Bahria oasis desert, Egypt. Nutrition and health, 19(4): 237-256. doi: https://doi.org/10.1177/ 026010600801900401

Abbott, S. L.; Cheung, W. K. and Janda, J. M. (2003). The genus Aeromonas: biochemical characteristics, atypical reactions, and phenotypic identification schemes. Journal of Clinical Microbiology, 41(6): 2348-2357.

Abdel-Aziz, M.; Eissa, A. E.; Hanna, M. and Okada, M. A. (2013). Identifying some pathogenic Vibrio/Photobacterium species during mass mortalities of cultured Gilthead seabream (Sparus aurata) and European seabass (Dicentrarchus labrax) from some Egyptian coastal provinces. International Journal of Veterinary 
Science and Medicine, 1(2): 87-95. doi: https://doi.org/10.1016/ j.ijvsm. 2013. 10.004

Abdelaziz, M.; Ibrahem, M. D.; Ibrahim, M. A.; Abu-Elala, N. M. and Abdelmoneam, D. A. (2017). Monitoring of different vibrio species affecting marine fishes in Lake Qarun and Gulf of Suez: Phenotypic and molecular characterization. The Egyptian Journal of Aquatic Research, 43(2): 141-146. doi: https://doi.org/10.1016/j.ejar.2017.06.002

Abram, Q. H.; Dixon, B. and Katzenback, B. A. (2017). Impacts of low temperature on the teleost immune system. Biology, 6(4): 39. doi: https://doi.org/10.3390/biology6040039

Abu-Elala, N. M.; Abd-Elsalam, R. M.; Marouf, S.; Abdelaziz, M. and Moustafa, M. (2016). Eutrophication, ammonia intoxication, and infectious diseases: interdisciplinary factors of mass mortalities in cultured Nile tilapia. Journal of aquatic animal health, 28(3): 187-198. doi: https://doi.org/10.1080/ 08997659.2016.1185050

Agius, C. and Roberts, R. (2003). Melanomacrophage centres and their role in fish pathology. Journal of fish diseases, 26(9): 499-509.

Aly, S.; Eissa, I.; Badran, A.; Elamie, M. and Hussain, B. (2005). Pathological studies on encysted metacercariae infections among some freshwater fish in Egyptian Aquaculture. Proceedings of Duetscher Tropentag, Hohenheim University, Stuttgart, Germany: 11-13.

APHA (1981). Standard methods for the examination of water and wastewater: APHA American Public Health Association.

Austin, B. and Austin, D. (1993). Bacterial fish pathogen, Disease of farmed and wild fish, 2: 111-117.

Austin, B. and Austin, D. (2007). Characteristics of the pathogens: Gram-negative bacteria. "Bacterial Fish Pathogens: Diseases of Farmed and Wild Fish" 81-150. doi: https://doi.org/10.1007/978-1-4020-6069-4_4

Austin, B. and Austin, D. A. (2012). Bacterial fish pathogens (Vol. 481): Springer.

Barker, D.; Allan, G.; Rowland, S. and Pickles, J. (2002). A guide to acceptable procedures and practices for aquaculture and fisheries research. NSW Fisheries Animal Care and Ethics Committee, NSW Fisheries: Sydney.

Baylis, H. (1947). LXXIX. - A new acanthocephalan from an East African freshwater fish. Journal of Natural History, 14(120): 861-868.

Bayoumy, M. E.; El-Hady, A.; Osman, K. and Osman, H. A. (2006). Site adaptations of Acanthogyrus (Acanthosentis) tilapiae: Observations through light and scanning electron microscopy. Journal of veterinary science, 7(4): 339-342. doi: https://doi.org/10.4142/jvs.2006.7.4.339

Bowers, J.; Mustafa, A.; Speare, D. J.; Conboy, G. A.; Brimacombe, M.; Sims, D. E. and Burka, J. F. (2000). The physiological response of Atlantic salmon, Salmo salar L., to a single experimental challenge with sea lice, Lepeophtheirus salmonis. Journal of fish diseases, 23(3): 165-172. doi: https://doi.org/10.1046/j.1365-2761.2000.00225.x

Buller, N. B. (2014). Bacteria and Fungi from Fish and other Aquatic Animals, a practical identification manual, Cabi. 
Bacterial and Parasitic Co-infection in the wild Nile tilapia (Oreochomis niloticus)

Caffara, M.; Locke, S. A.; Cristanini, C.; Davidovich, N.; Markovich, M. P. and Fioravanti, M. L. (2016). A combined morphometric and molecular approach to identifying metacercariae of Euclinostomum heterostomum (Digenea: Clinostomidae). Journal of Parasitology, 102(2): 239-248. doi: https://doi.org/10.1645/15-823

Cai, S.-H.; Wu, Z.-H.; Jian, J.-C.; Lu, Y.-S. and Tang, J.-F. (2012). Characterization of pathogenic Aeromonas veronii bv. veronii associated with ulcerative syndrome from Chinese longsnout catfish (Leiocassis longirostris Günther). Brazilian Journal of Microbiology, 43(1): 382-388.

Chen, Q.; Yan, Q.; Wang, K.; Zhuang, Z. and Wang, X. (2008). Portal of entry for pathogenic Vibrio alginolyticus into large yellow croaker Pseudosciaena crocea, and characteristics of bacterial adhesion to mucus. Diseases of aquatic organisms, 80(3): 181-188. doi: https://doi.org/10.3354/dao01933

Coward, K. and Little, D. (2001). Culture of the'aquatic chicken': present concerns and future prospects, Biologist (London, England), 48(1): 12-16.

Dahdouh, B.; Basha, O.; Khalil, S. and Tanekhy, M. (2016). Molecular characterization, antimicrobial susceptibility and salt tolerance of Aeromonas hydrophila from fresh, brackish and marine fishes. Alexandria Journal of Veterinary Sciences, 48(2): 46-53.

de la Cruz, C. P. P.; Bandal, M.; Avila Jr, A. and Paller, V. G. V. (2013). Distribution pattern of Acanthogyrus sp.(acanthocephala: Quadrigyridae) in nile tilapia (Oreochromis niloticus l.) from sampaloc lake, philippines. Journal of Nature Studies, 12(1): 1-10.

Dezfuli, B.; Bo, T.; Lorenzoni, M.; Shinn, A. and Giari, L. (2015). Fine structure and cellular responses at the host-parasite interface in a range of fish-helminth systems. Veterinary parasitology, 208(3-4): 272-279. doi: https://doi.org/10.1016/j.vetpar.2015.01.002

Diggles, B.; Carson, J.; Hine, P.; Hickman, R. and Tait, M. (2000). Vibrio species associated with mortalities in hatchery-reared turbot (Colistium nudipinnis) and brill (C. guntheri) in New Zealand. Aquaculture, 183(1-2): 1-12. doi: https://doi.org/10.1016/s0044-8486(99)00280-x

Dönges, J. (1974). The life cycle of Euclinostomum heterostomum (Rudolphi, 1809)(Trematoda: Clinostomatidae). International Journal for Parasitology, 4(1): 79-90.

Ebtsam, S. H. A.; Amina Mohamed Al tayip; Sary Khaleel Abd ELghaffar Nasr; Gehan Mohamed Sayed and kamel, A. A. E. h. E. (2017). Acanthogyrus tilapiae infection in wild and cultured Nile tilapia Oreochromis Niloticus. Assiut Vet. Med., 63 ( 155).

Eissa, I. (2002). Parasitic fish diseases in Egypt, Dar El-Nahda El-Arabia Publishing, 32: 149-160.

Eissa, I.; Derwa, H.; El-Lamei, M.; Desuki, A.; Zaki, M. and El-Sheshtawy, H. (2013). Iron in water and some marine fishes in relation to vibriosis at Lake Temsah. Life Sci J., 10(3): 2520-2528.

Eissa , I.; Eldin, A.; Abou-Elgheit, S.; Dessuki, A.; Hassanin, A. and Mostafa, L. (2019). Advanced diagnosis of vibriosis among some marine fishes in lake 
Temsah, Egypt. Journal of the Hellenic Veterinary Medical Society, 70(1): 13391346. doi: https://doi.org/10.12681/jhvms.20338

El-Ashram, A. (2002). On Aeromonas hydrophila infection among cultured tilapias: a biological, histopathological and management study. Egyptian Journal of Aquatic Biology and Fisheries, 6(3): 181-202.

El-Sayed; Algammal, A.; Abouel-Atta, M.; Mabrok, M. and Emam, A. (2019). Pathogenicity, genetic typing, and antibiotic sensitivity of Vibrio alginolyticus isolated from Oreochromis niloticus and Tilapia zillii. Rev. Med. Vet., 170: 8086.

Elamparithi, P. and Ramanathan, N. (2011). Identification of Vibrio parahaemolyticus isolates by PCR targeted to the toxR gene. Int. J. Pharm. Biol. Arch, 2: 17351737.

Evans, J. J.; Pasnik, D. J.; Brill, G. C. and Klesius, P. H. (2006). Un-ionized ammonia exposure in Nile tilapia: toxicity, stress response, and susceptibility to Streptococcus agalactiae. North American Journal of Aquaculture, 68(1): 23-33.

Garrity, G. M. (2005). Systematic bacteriology. The Proteobacteria, Part C: The Alpha-, Beta-, Delta-, and Epsilonproteobacteria, "Bergey's Manual Trust, Department of Microbiology and Molecular Genetics", 2.

Gauthier, G.; Lafay, B.; Ruimy, R.; Breittmayer, V.; Nicolas, J.-L.; Gauthier, M., and Christen, R. (1995). Small-Subunit rRNA Sequences and Whole DNA Relatedness Concur for the Reassignment of Pasteurella piscicida (Snieszko et al.) Janssen and Surgalla to the Genus Photobacterium as Photobacterium damsela subsp. piscicida comb. nov. International Journal of Systematic and Evolutionary Microbiology, 45(1): 139-144. doi: https://doi.org/10.1099/00207713-45-1-139

Glibert, P. M.; Landsberg, J. H.; Evans, J. J.; Al-Sarawi, M. A.; Faraj, M.; AlJarallah, M. A. . . . and Powell, C. (2002). A fish kill of massive proportion in Kuwait Bay, Arabian Gulf, 2001: the roles of bacterial disease, harmful algae, and eutrophication. Harmful Algae, 1(2): 215-231.

Gordon, L.; Giraud, E.; Ganière, J. P.; Armand, F.; Bouju-Albert, A.; De la Cotte, N. . . a and Le Bris, H. (2007). Antimicrobial resistance survey in a river receiving effluents from freshwater fish farms. Journal of Applied Microbiology, 102(4): 1167-1176.

Harper, C. and Wolf, J. C. (2009). Morphologic effects of the stress response in fish. ILAR journal, 50(4): 387-396.

Hossain, M. D.; Hossain, M. K. and Rahman, M. H. (2007). Water quality parameters and incidence of fish diseases in some Water bodies in Natore, Bangladesh. Journal of Life and Earth Science, 2(2): 27-30.

Ismail; S.; Saleh, W. and Zaki, M. (2011). Studies on Vibrio infection in cultured freshwater fish. Life Science Journal-Acta Zhengzhou University Overseas Edition 8(4): 155-162.

Iwanowicz, D. (2011). Overview on the effects of parasites on fish health. Report of Leetown Science Center. US Geological Survey. Available from http://www. lsc. usgs. gov/files/D\% 20Iwanowicz, 20: 2011.

Janeway, C.; Travers, P.; Walport, M. and Shlomchik, M. (2004). Immunobiology, Garland Science, New York. 
Kim, Y. B.; Okuda, J.; Matsumoto, C.; Takahashi, N.; Hashimoto, S. and Nishibuchi, M. (1999). Identification of Vibrio parahaemolyticus strains at the species level by PCR targeted to the toxR gene. Journal of Clinical Microbiology, 37(4): 1173-1177. doi: https://doi.org/10.1128/jcm.37.4.1173-1177.1999

Korun, J. and Timur, G. (2005). The first pasteurellosis case in cultured sea bass (Dicentrarchus labrax L.) at low marine water temperatures in Turkey. The Israeli Journal of Aquaculture- Bamidgeh, 57(3): 197.206.

Korun, J., and Timur, G. (2008). Marine vibrios associated with diseased sea bass (Dicentrarchus labrax) in Turkey. Journal of FisheriesSciences, 2(1): 66-76.

Kotob, M. H.; Menanteau-Ledouble, S.; Kumar, G.; Abdelzaher, M. and ElMatbouli, M. (2017). The impact of co-infections on fish: a review. Veterinary research, 47(1): 98. doi: https://doi.org/10.1186/s13567-016-0383-4

Lee, J.; Lee, W.-J.; Kim, M.-J.; Cho, Y.-S.; Lee, J.-S.; Lee, H.-J. . . and Kim, K.-S. (2015). Comparative Evaluation of the VITEK 2 System and Species-specific PCR Methods for the Detection of Vibrio Species Isolated from Shrimp. Journal of Food Hygiene and Safety, 30(3): 281-288.

Lovshin, L. (1997). Worldwide tilapia culture. Paper presented at International de Aquicultura (pp. 96-116).

Lunder, T.; Sørum, H.; Holstad, G.; Steigerwalt, A. G.; Mowinckel, P. and Brenner, D. J. (2000). Phenotypic and genotypic characterization of Vibrio viscosus sp. nov. and Vibrio wodanis sp. nov. isolated from Atlantic salmon (Salmo salar) with'winter ulcer'. International journal of systematic and evolutionary microbiology, 50(2): 427-450. doi: https://doi.org/10.1099/00207713-50-2-427

Mahdy, O. A.; Abdel-Maogood, S. Z.; Mohammed, F. F. and Salem, M. A. (2017). Effect of Verbesina Alternifolia and Mentha Piperita Oil Extracts on Newly Excysted Metacercaria of Euclinostomum Heterostomum (Rudolphi, 1809)(Digenea: Clinostomatidae) from Naturally Infected Kidneys of Tilapia Zillii in Egypt. Journal of the Egyptian Society of Parasitology, 240(6170): 1-9. doi: https://doi.org/10.12816/0049782

Mendes-Marques, C. L.; Hofer, E. and Leal, N. C. (2013). Development of duplexPCR for identification of Aeromonas species. Revista da Sociedade Brasileira de Medicina Tropical, 46(3): 355-357. doi: https://doi.org/10.1590/0037-8682-13442013

Nickol, B. B. (2006). Phylum Acanthocephala. In "P. T. K. Woo (Ed.), Fish Diseases and Disorders" (Second Edition. : Protozoan and Metazoan Infections ed., Vol. I, pp. 2006; 2444-), UK: CAB International, Wallingford.

Noga, E. (2010). Fish disease: diagnosis and treatment: John Wiley \& Sons.

Plumb, J. (1999). Health maintenance and principal microbial diseases of cultured fishes Iowa State University Press. Ames, IO, USA. doi: https://doi.org/10.1201/9781351073141-14

Plumb, J.; Grizzle, J. and Defigueiredo, J. (1976). Necrosis and bacterial infection in channel catfish (Ictalurus punctatus) following hypoxia. Journal of wildlife diseases, 12(2): 247-253.

Sambrook, J. and Fritscgh, E. (1989). Molecular coloning. A laboratory manual. Vol. Cold spring Harbor Laboratory press, New York. Method validation for Aflatoxin 
M1 determination in yoghurt using immune-affinity column clean up prior to high-performance liquid chromatography. Toxicol and health, 27(7): 629-635.

Sarkar, M. and Rashid, M. M. (2012). Pathogenicity of the bacterial isolate Aeromonas hydrophila to catfishes, carps and perch. Journal of the Bangladesh Agricultural University, 10(452-2016-35552): 157-161.

Shehata, S. M.; Mohammed, R. A.; Ghanem, M. H.; Abdelhadi, Y. M. and Radwan, M. K. (2018). Impact of the stresses environmental condition on the prevalence of parasite in fresh water aquaculture. Journal of FisheriesSciences. com, 12(2): 919.

Soliman, N. F. and Yacout, D. M. (2016). Aquaculture in Egypt: status, constraints and potentials. Aquaculture international, 24(5): 1201-1227. doi: https://doi.org/10.1007/s10499-016-9989-9

Soumet, C.; Ermel, G.; Fach, P. and Colin, P. (1994). Evaluation of different DNA extraction procedures for the detection of Salmonella from chicken products by polymerase chain reaction. Lett Appl Microbiol, 19(5): 294-298. doi: https://doi.org/10.1111/j.1472-765x.1994.tb00458.x

Stiles, C. W. and Hassall, A. (1905). The determination of generic types: and a list of roundworm genera, with their original and type species: US Department of Agriculture, Bureau of Animal Industry.

Stintzi, A. and Raymond, K. N. (2000). Amonabactin-mediated iron acquisition from transferrin and lactoferrin by Aeromonas hydrophila: direct measurement of individual microscopic rate constants. JBIC Journal of Biological Inorganic Chemistry, 5(1): 57-66. doi: https://doi.org/10.1007/p100010655

Szalai, A. J. and Dick, T. A. (1987). Intestinal pathology and site specificity of the acanthocephalan Neoechinorhynchus carpiodi Dechtiar, 1968, in quillback, Carpiodes cyprinus (Lesueur). The Journal of parasitology: 467-475. doi: https://doi.org/10.2307/3282123

Taher, G. (2009). Some studies on metacercarial infection in Oreochromis niloticus in Assiut Governorate and their role in transmission of some trematodes to dogs. Assiut University Bulletin for Environmental Researches, 12(1): 63-79.

Wanstall and Terry, S. (1984). A study of the pathobiology of Pomphorhynchus laevis Muller in freshwater fish. doi: https://doi.org/10.1111/j.13652761.1988.tb00750.x

WHO (1993). Guidelines for drinking-water quality: World Health Organization.

Xu, D. H.; Shoemaker, C. and Klesius, P. (2007). Evaluation of the link between gyrodactylosis and streptococcosis of Nile tilapia, Oreochromis niloticus (L.). Journal of fish diseases, 30(4): 233-238. doi: https://doi.org/10.1111/j.13652761.2007.00806.x

Yardımcı, B. and Aydın, Y. (2011). Pathological findings of experimental Aeromonas hydrophila infection in Nile tilapia (Oreochromis niloticus). Ankara Üniversitesi Veteriner Fakültesi Dergisi, 58(1): 47-54.

Yildiz, H. Y.; Bekcan, S.; Benli, A. K. and Akan, M. (2005). Some blood parameters in the eel (Anguilla anguilla) spontaneously infected with Aeromonas hydrophila. Israel Journal of Veterinary Medicine, 60(3): 91. 
Younes, A.; Fares, M.; Gaafar, A. and Mohamed, L. A. (2016). Isolation of Vibrio alginolyticus and Vibrio vulnificus strains from cultured Oreochromis niloticus around Qarun Lake, Egypt. Global Veterinaria, 16(1): 01-05.

Zaman, R. and Khalequzzaman, M. (2013). Research Article Pathogenecity Test of Aeromonas Isolated from Motile Aeromonas Septicemia (MAS) Infected Nile Tilapia on Some Freshwater Fish Forhad Karim Saikot Department of Genetic Engineering and Biotechnology, University of Rajshahi, Rajshahi, 6205, Bangladesh. Science International, 1(9): 325-329. 